\title{
Activity-based Learning (ABL) of Power Systems-I (PS-I) Course
}

\author{
Jonnalagadda Venkatesh \\ Assistant Professor, EEE, \\ Shri Vishnu Engineering College for Women (A), \\ Bhimavaram
}

\begin{abstract}
In this 21' st century, radical changes have existed in the teaching-learning system. Only a few students are showing interest in learning information from the teacher rest is purely depending on GOOGLE, Internet resources, etc. In general, many students simply overlook any course if they feel complications in learning it. So for such types of courses as a teacher, we have to create interest among the students through Activity-Based Learning (ABL) which acts as a bridge to cross a typical water pond (Course). Classroom activities will give simultaneous benefits to both students as well as for teachers (students can overcome the difficulty in learning typical course teachers can deliver a topic in a variety of approaches effectively). Collaborative learning among students will create a healthy learning environment and also emphasize student's performance, teamwork. Any student tries to identify a solution for a given problem but, through collaborative learning with a group of people will give an optimized solution to the same problem. Power Systems-I (PS-I) is an essential subject in Electrical Engineering. Along with conventional learning of any course Activity-Based Learning (ABL) will overcome some of the difficulties, I am sharing my teaching experiences in the PS-I course of activities like word search, charts/posters, mindmaps, interdisciplinary lectures, snake and ladder, puzzles, etc.
\end{abstract}

Index Terms-Activity-Based Learning (ABL), EDMODO tool, Power Systems - I (PS-I).

\section{INTRODUCTION}

THE basic human needs of man are food, cloth, and shelter as of today power had become a 4th basic need. Humans depend on the environment, with those resources a man had initiated in search of science. In this 21 'st century, technology has been upgraded a lot with many inventions/discoveries which made our life very much comfortable and convenient too. So to operate any electrical device we need Electric Power. Exactly today scenario is man's life is incomplete without Electric Power. Everyone can utilize the electric power for our needs at the same time have a responsibility to save it for future generations. Power Systems - I (PS-I) is a necessary subject in the discipline of Electrical Engineering. Electric power can generate using both renewable and non-renewable energy resources.

\section{LIST OF ACTIVITIES IMPLEMENTED}

- IOT (Identification of Topic)

- Posters/Charts

- Word Search

- $\quad$ Business with Temple Run Version 2.0

- Mind Maps

- Case Study PPT's

- Interdisciplinary
- $\quad$ Snake and Ladder

- Mapping/Scratch Cards

- Puzzles

\section{A. Identification of Topic (IOT)}

Initially, I had created a variety of images consist of hidden topic names, parts of an apparatus, a mistake in the content. I asked students to identify the hidden topics/parts/mistakes in the image. The objective of this activity is to identify, recollect the technical words in the PS-I course and also help them to perform well in the examinations to get a good score. I am sharing a sample glimpse of this activity.

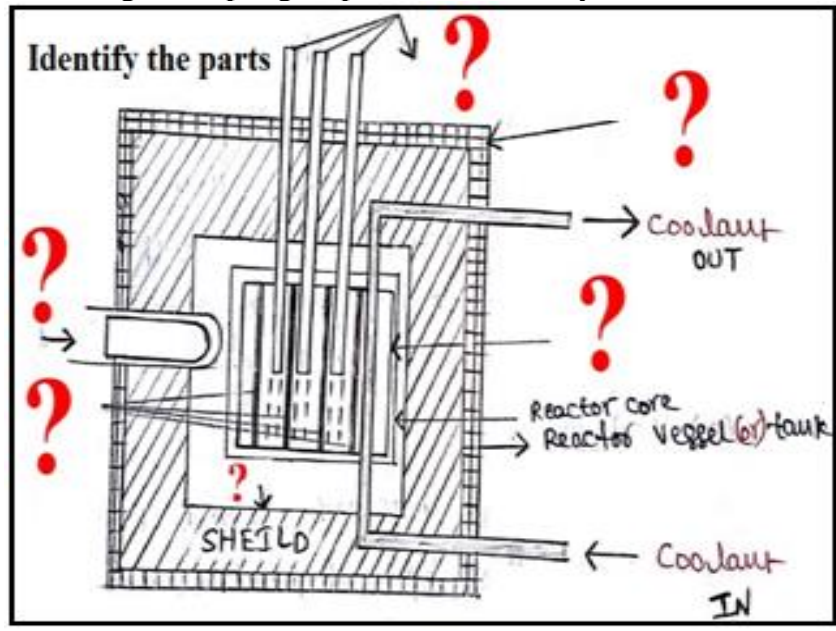

B. Posters/Charts

Students have drawn various types of power plants that are exploring their creativity. The purpose of the charts is to improve drawing skills and present diagrams/circuits well in the examination. I am giving out a sample glimpse of this activity.

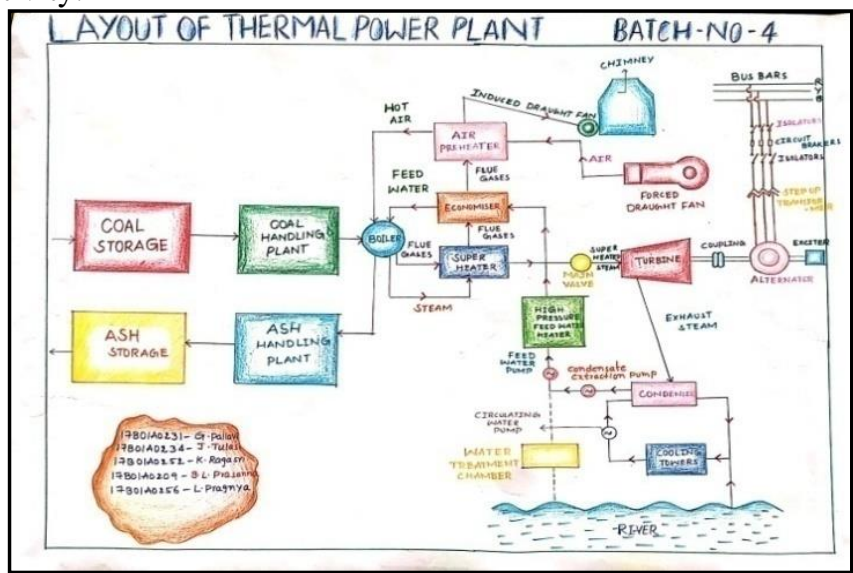




\section{Word Search}

Initially, I had placed technical words, components names of PS-I in the $12 \times 12$ table in various directions (left to right, right to left, top to bottom, bottom to top, diagonally from top to bottom and diagonally bottom to top from both sides (left, right)). The objective of this activity is to search technical words in the PS-I course.

\begin{tabular}{|c|c|c|c|c|c|c|c|c|c|c|c|}
\hline Z & E & K & U & F & F & Y & V & M & L & J & A \\
\hline H & C & N & D & R & H & T & N & I & L & P & L \\
\hline G & O & Q & E & E & A & U & T & E & I & J & T \\
\hline Y & N & S & N & H & Q & N & G & Y & S & L & E \\
\hline E & O & K & S & Y & F & A & I & D & N & R & R \\
\hline N & M & G & I & J & S & W & P & U & F & L & N \\
\hline M & I & Q & M & Q & H & Y & Y & O & M & V & A \\
\hline I & S & Z & E & W & R & G & I & P & C & J & T \\
\hline H & E & Q & T & F & F & E & E & D & E & R & O \\
\hline C & R & H & E & A & T & J & R & B & D & N & R \\
\hline X & Q & O & R & P & E & D & P & K & W & K & U \\
\hline G & W & U & Z & X & Q & R & E & L & I & O & B \\
\hline
\end{tabular}

\section{Business with Temple Run Version 2.0}

In this PS-I Business activity, a total of 10 Batches had participated. Based on their performance they got profit (or) loss. The procedure for this activity is as follows.

- Purchase of thermal power plant components by playing Temple Run Version 2.0 game treated as temple run score.

- By rolling a die, following general rules of the indoor business game students played for 20 minutes, score at the end of the time is treated as a business game score.

Total Score $=$ Temple Run Score + Business game Score Out of 10 batches participated in this activity

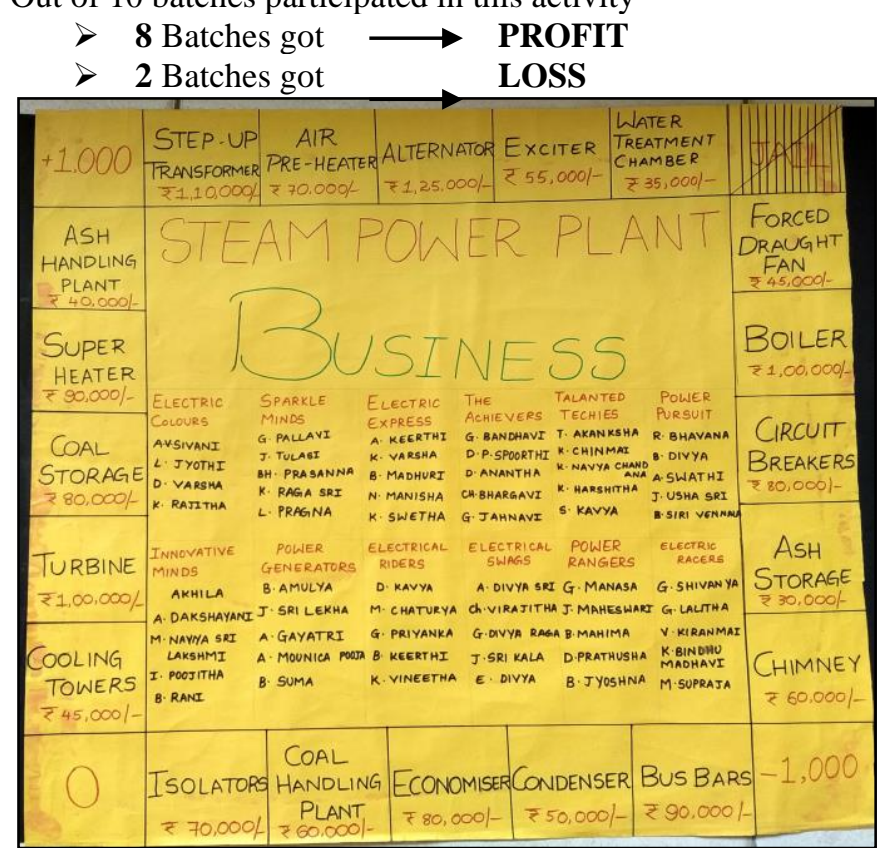

The below figure shows the statistical representation of the Team total score Vs Team number.

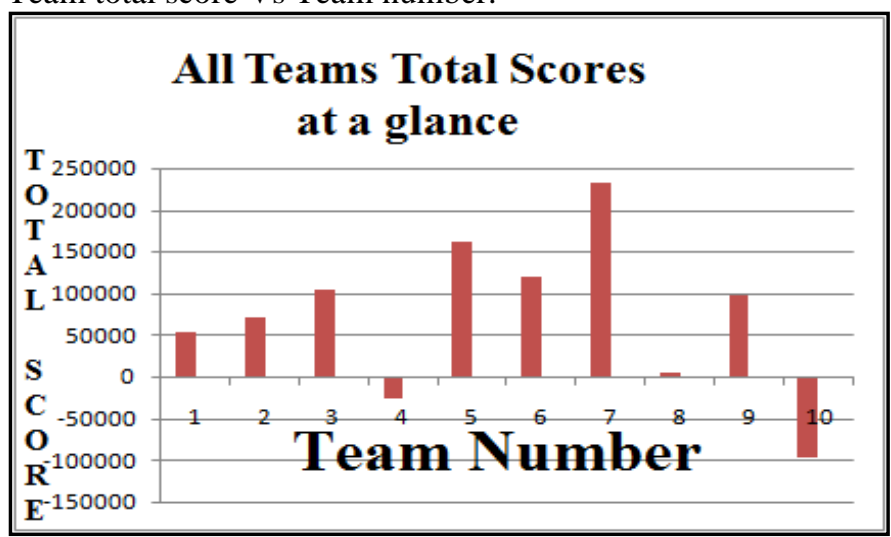

\section{E. Mind Maps}

Students have drawn a variety of mind maps by interfacing PS-I topics with aspects of societal, environment, etc. By these mind maps students elevated PS-I concepts in a different approach, so that they can remember the concepts for a long time. There is quite a difference between Mind maps and posters/Charts. I'm sharing a sample mind map representing the layout of a nuclear power plant that looks like a side view of a train.

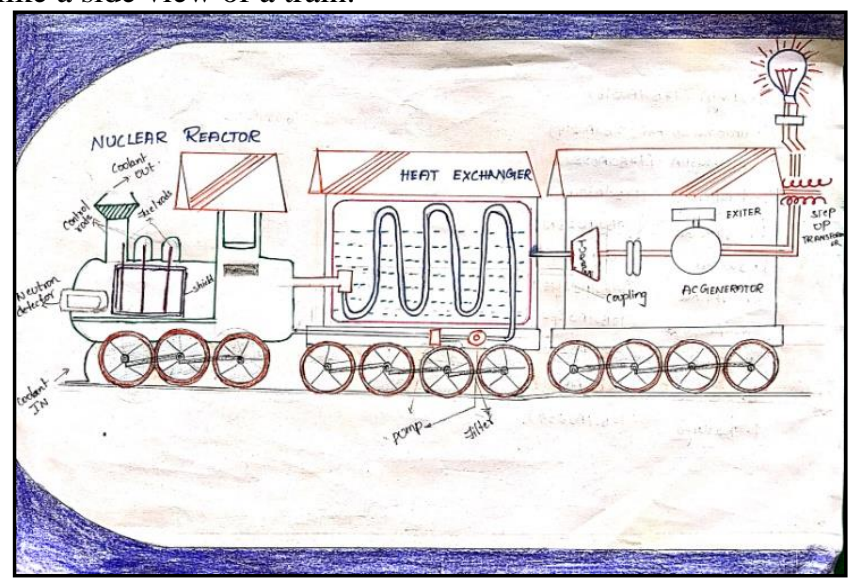

\section{F. Case Study PPT's}

A case study defines as a research strategy, an empirical inquiry that investigates the phenomenon within its real-life context. These case studies formulate learners to direct towards a specific topic in a variety of ways. A Case Study is quite different from a general topic.

Through this activity, students will get to know about problems/issues which are happening/happened in the Power System sector. Initially, I allotted various case study topics to 12 batches in the class (taking references from the daily newspapers/Wikipedia/Google). I have set specific guidelines for preparing PowerPoint presentations (PPT). 


\begin{tabular}{|c|c|c|c|c|}
\hline \multicolumn{5}{|c|}{ Assessment Rubrics of case study PPT's } \\
\hline $\begin{array}{l}\mathbf{S} \\
\dot{\mathbf{N}} \\
\text { o. }\end{array}$ & Rubrics & $\begin{array}{c}\text { Excellent } \\
\text { (5) }\end{array}$ & $\begin{array}{l}\text { Good } \\
\text { (4) }\end{array}$ & $\begin{array}{l}\text { Average } \\
\text { (3) }\end{array}$ \\
\hline 1 & Communication & $\begin{array}{c}\text { Very } \\
\text { Good } \\
\text { Language, } \\
\text { Verbal \& } \\
\text { Non- } \\
\text { Verbal }\end{array}$ & $\begin{array}{l}\text { Language, } \\
\text { Verbal \& } \\
\text { Non-Verbal } \\
\text { is OK }\end{array}$ & $\begin{array}{c}\text { Language, } \\
\text { Verbal \& } \\
\text { Non-Verbal } \\
\text { is to be } \\
\text { improved }\end{array}$ \\
\hline 2 & Team Involvement & $\begin{array}{c}\text { All Team } \\
\text { Members } \\
\text { are } \\
\text { Involved } \\
\text { Much } \\
\end{array}$ & $\begin{array}{l}\text { All Team } \\
\text { Members } \\
\text { are } \\
\text { Involved }\end{array}$ & $\begin{array}{c}\text { Only Few } \\
\text { Team } \\
\text { Members } \\
\text { are } \\
\text { Involved } \\
\end{array}$ \\
\hline 3 & $\begin{array}{l}\text { PPT } \\
\text { Work }\end{array}$ & $\begin{array}{l}\text { Included } \\
\text { Much } \\
\text { relevant } \\
\text { Articles, } \\
\text { Glimpse }\end{array}$ & $\begin{array}{c}\text { Included } \\
\text { relevant } \\
\text { Articles, } \\
\text { Glimpses }\end{array}$ & $\begin{array}{c}\text { Have to } \\
\text { include } \\
\text { better } \\
\text { points, } \\
\text { Glimpse } \\
\text { which suits } \\
\text { their topic }\end{array}$ \\
\hline 4 & $\begin{array}{l}\text { EDMODO tool } \\
\text { Poll Votes }\end{array}$ & Highest & $<$ Highest & $<<$ Highest \\
\hline 5 & Time Management & $\begin{array}{l}\text { Utilized } \\
\text { almost } \\
\text { Given } \\
\text { time }\end{array}$ & $\begin{array}{c}\text { completed } \\
\text { in a short } \\
\text { time but } \\
\text { within only }\end{array}$ & $\begin{array}{l}\text { Used more } \\
\text { than given } \\
\text { time }\end{array}$ \\
\hline
\end{tabular}

\begin{tabular}{|c|c|c|}
\hline Topic Name & Newspaper/Website & Date \\
\hline $\begin{array}{c}\text { Indian coal allocation } \\
\text { scam }\end{array}$ & Wikipedia/Google & 2004-2009 \\
\hline $\begin{array}{c}\text { 'Water scarcity may hit } \\
\text { thermal power' }\end{array}$ & The Hindu & JANUARY 16, 2018 \\
\hline $\begin{array}{c}\text { Coal shortage begins to } \\
\text { hit power generation }\end{array}$ & The Hindu & 18-Oct-2018 \\
\hline $\begin{array}{c}\text { Andhra Pradesh to set } \\
\text { up two mega super } \\
\text { critical thermal power } \\
\text { plants }\end{array}$ & $\begin{array}{c}\text { DECCAN } \\
\text { CHRONICLE }\end{array}$ & 16-Dec-2015 \\
\hline Bhopal gas tragedy & Wikipedia/Google & 2-3 December 1984 \\
\hline $\begin{array}{c}\text { Coal shortage hits } \\
\text { production at } \\
\text { Vijayawada thermal } \\
\text { power plant }\end{array}$ & Times of India & Nov-28,2017 \\
\hline $\begin{array}{c}\text { Severe shortage of coal } \\
\text { stares NTTPS }\end{array}$ & The Hindu & 14-Jun-2014 \\
\hline $\begin{array}{c}\text { Power producers urge } \\
\text { centre to speed up the } \\
\text { revival of gas-based } \\
\text { power plants }\end{array}$ & The Hindu & 30-Sep-2018 \\
\hline $\begin{array}{c}\text { Andhra Pradesh to get } \\
\text { another nuclear plant }\end{array}$ & $\begin{array}{c}\text { DECCAN } \\
\text { CHRONICLE }\end{array}$ & 22-Sep-2018 \\
\hline $\begin{array}{c}\text { Coal Ash In Telangana } \\
\text { and Andhra Pradesh } \\
\text { Sparks Concern }\end{array}$ & DECCAN & 7-Apr-2015 \\
\hline
\end{tabular}

Sample glimpses of case study PPT's

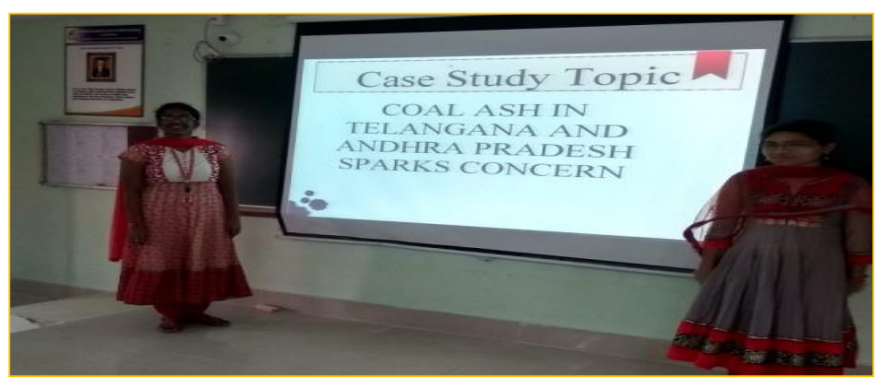

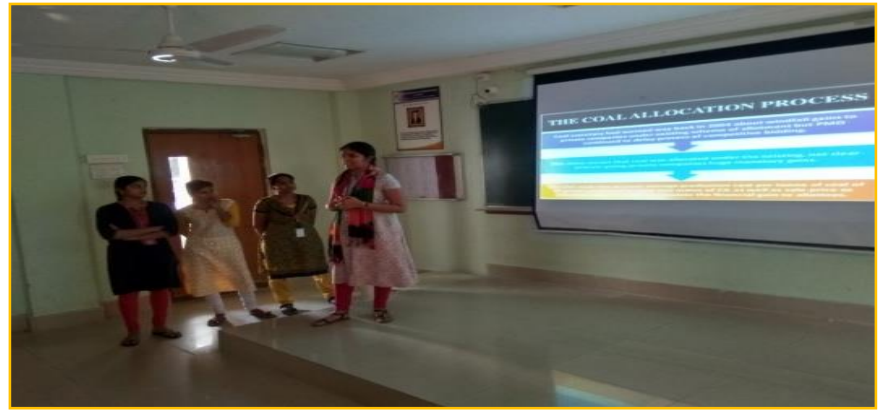

G. Interdisciplinary faculty lectures with student worksheets

In this activity, three faculty from different engineering disciplines had given individual lectures to II-EEE students.

\begin{tabular}{|c|c|ll|}
\hline S.No. & Branch of Faculty & \multicolumn{1}{c|}{ Name of the topic } \\
\hline \multirow{2}{*}{1} & $\begin{array}{c}\text { Computer Science } \\
\text { Engineering (CSE) }\end{array}$ & $\bullet$ Algorithms \\
& $\bullet$ Flowcharts \\
\hline 2 & Mechanical & C-Program \\
\hline \multirow{3}{*}{ Engineering (ME) } & $\succ$ & Steam Turbines \\
& Civil & $>$ Site Selection of power plants \\
& Engineering & $>$ Surveying \\
& (CE) & $>$ Soil Testing \\
\hline
\end{tabular}

The above lectured acts as prerequisite topics for understanding things behind the layout of thermal/nuclear/gas power plants etc. After completion of the above mentioned interdisciplinary lectures.

- Regarding CSE, some students presented layouts of various power plants in the form of algorithms, flow charts, and c-programs. I am sharing sample glimpses.

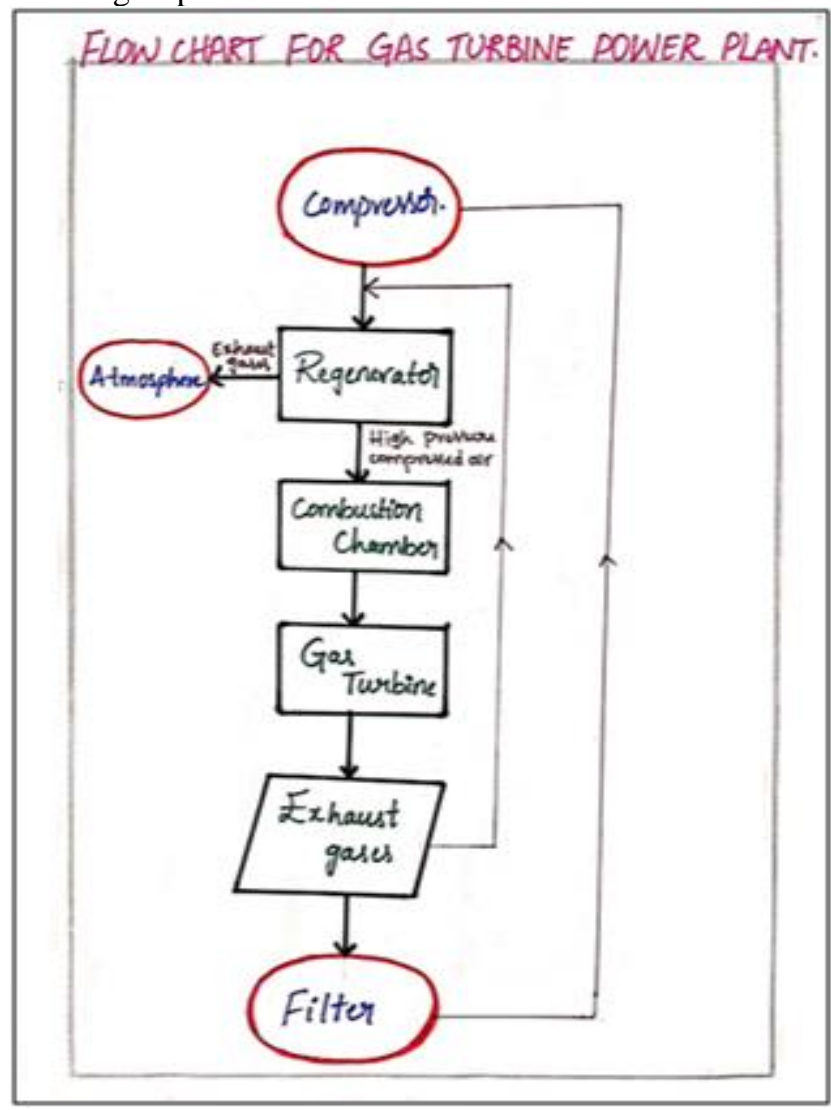



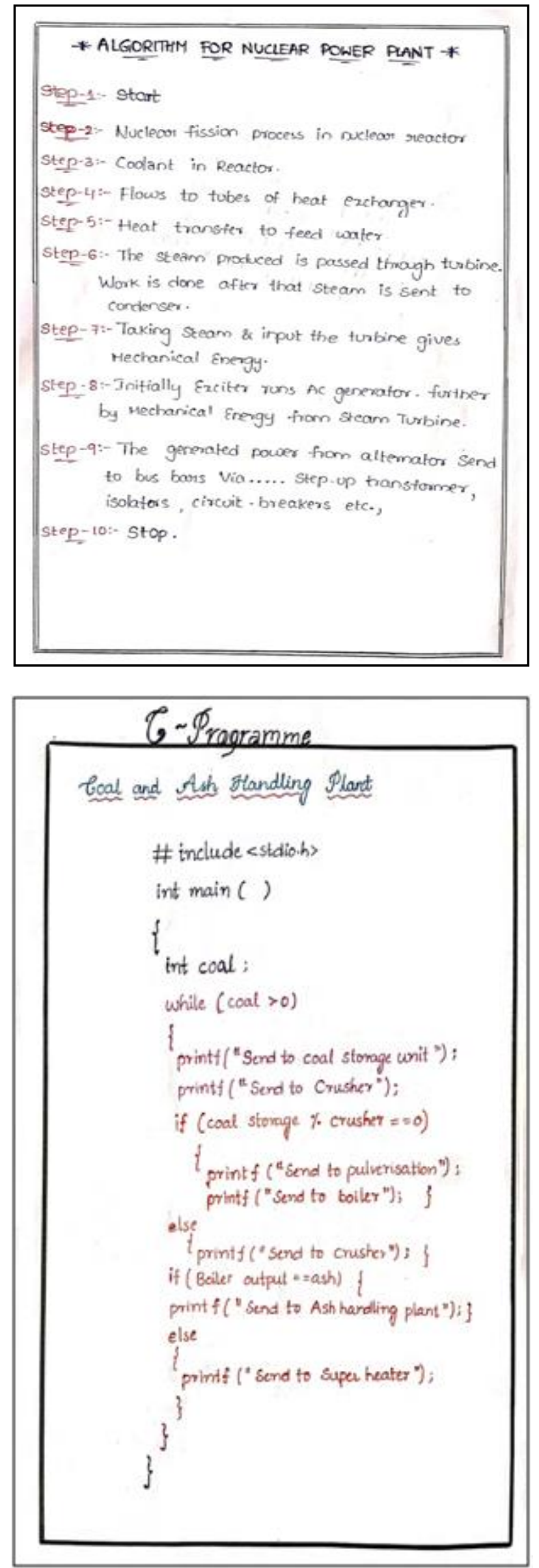

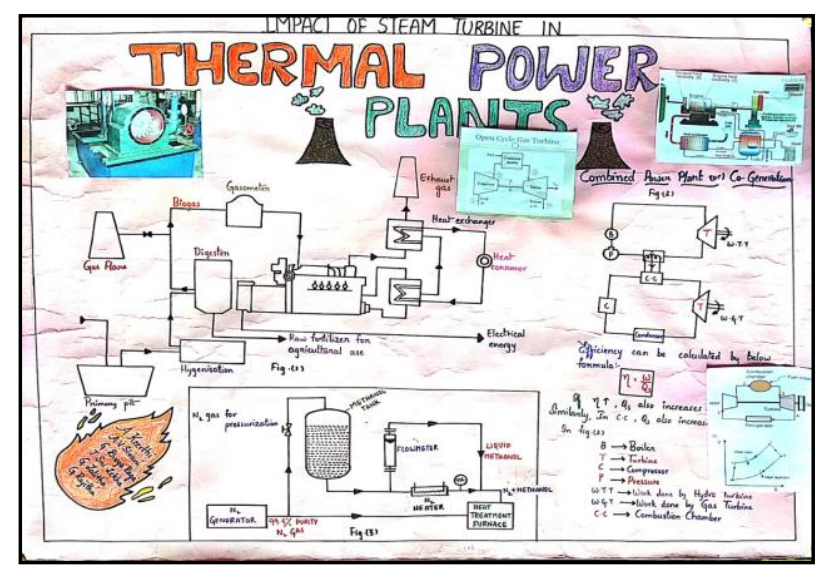

- Regarding ME, some students presented a poster on the co-generation concept, which improves the overall efficiency of the power plant. The below poster explained the role of ME components like steam turbines in the working of thermal/nuclear/gas power plants.

- Regarding CE, some students presented a poster consist of the below CE discipline topics.

\begin{tabular}{|c|c|c|}
\hline S. No. & Name of process & Tools/Methods \\
\hline 1 & Soil Testing & $\begin{array}{ll}\text { - } & \text { Liquid Limit Test } \\
\text { - } & \text { Permeability Test } \\
\text { - } & \text { Direct Shear Test } \\
\text { - } & \text { Tri- Axial Test } \\
\end{array}$ \\
\hline 2 & Surveying & $\begin{array}{ll}\text { - } & \text { Theodolite } \\
\text { - } & \text { Prism } \\
\text { - } & \text { Total Station }\end{array}$ \\
\hline
\end{tabular}

The below poster will shows the role of CE topics (soil testing methods, surveying tools) behind the establishment of thermal/nuclear/gas power plants.

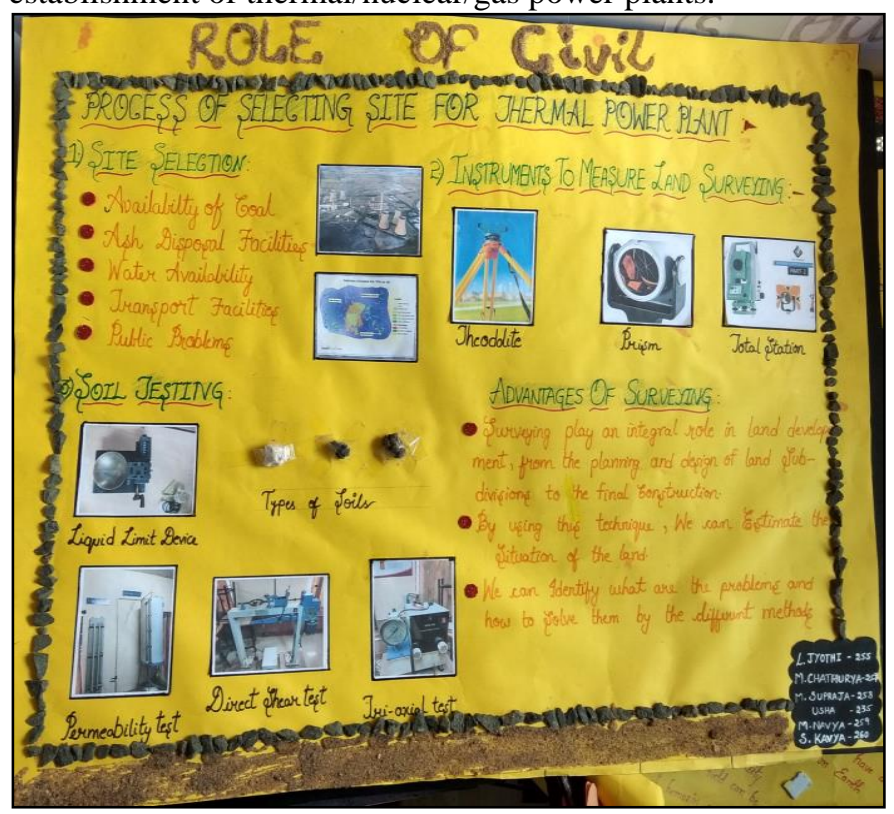

\section{H. Snake and Ladder}

Firstly, before the day of the activity, I divided total class students into batches and instructed them to prepare various types of bus-bar arrangements for snake and ladder activity. I had designed a snake and ladder chart, which consists of various Power system components like bus bars, circuit breakers, Sectionalization switch, Current Transformer 
(CT), Potential Transformer (PT), etc. in the blocks of different numbers. On the activity day, the activity gets started just by following the general rules of the snake and ladder game by rolling the die. I instructed all batches to play the game and collect various power system components using them to design any type of bus bar arrangement before reaching of 100 th block.

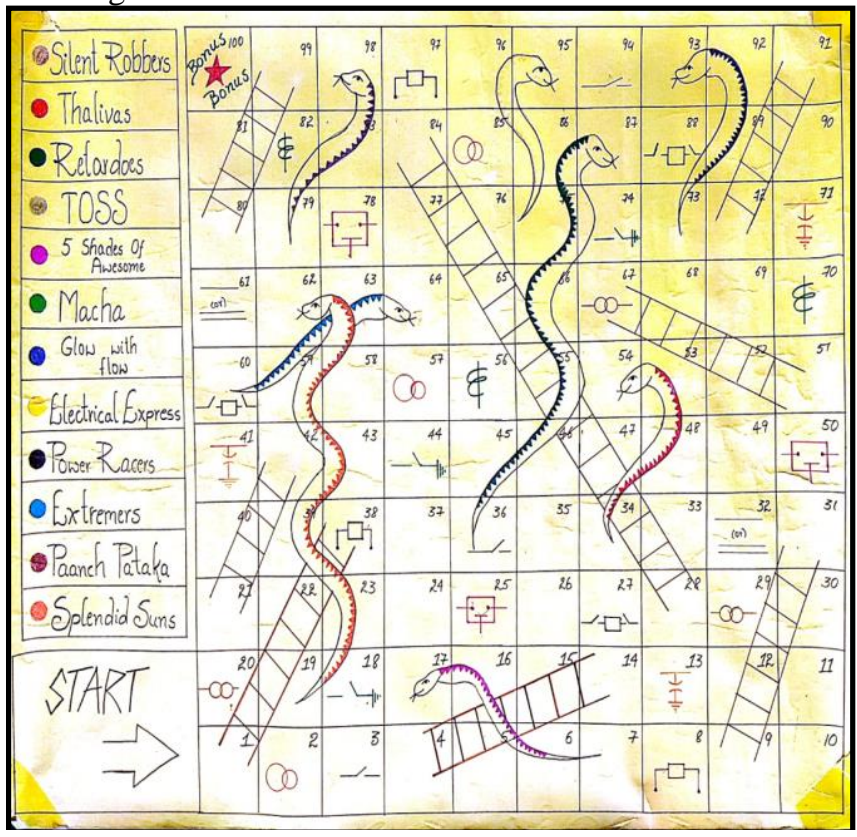

\section{Mapping/Scratch Cards}

Initially, I had prepared various quiz questions cards, answers cards, and scratch cards. I had separated, question cards on the left side, answer cards on the right side and asked batch-wise to map question cards with answer cards.

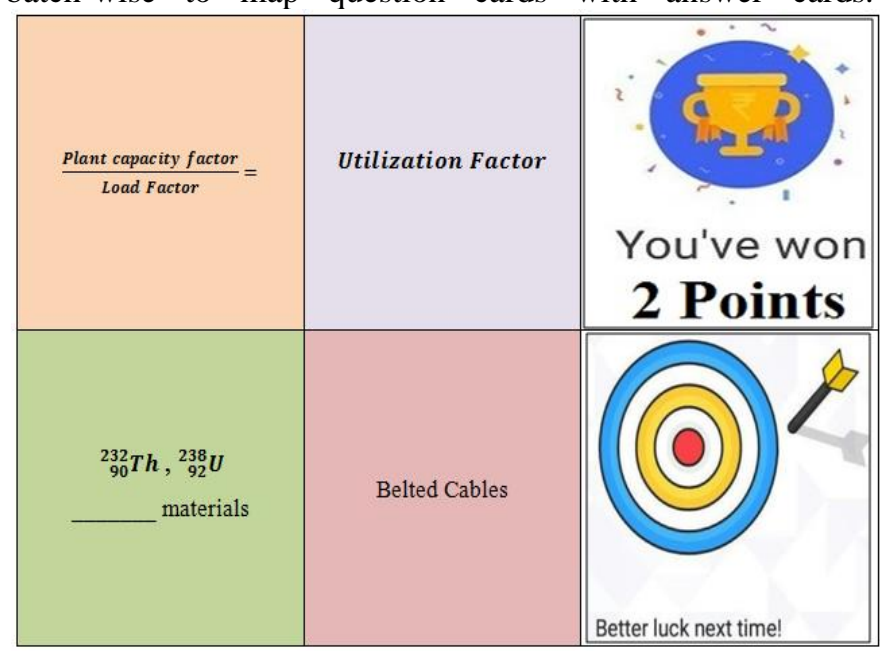

\section{J. Puzzles}

Initially, I had prepared various short answer questions in both vertical and horizontal positions combined to form a puzzle.

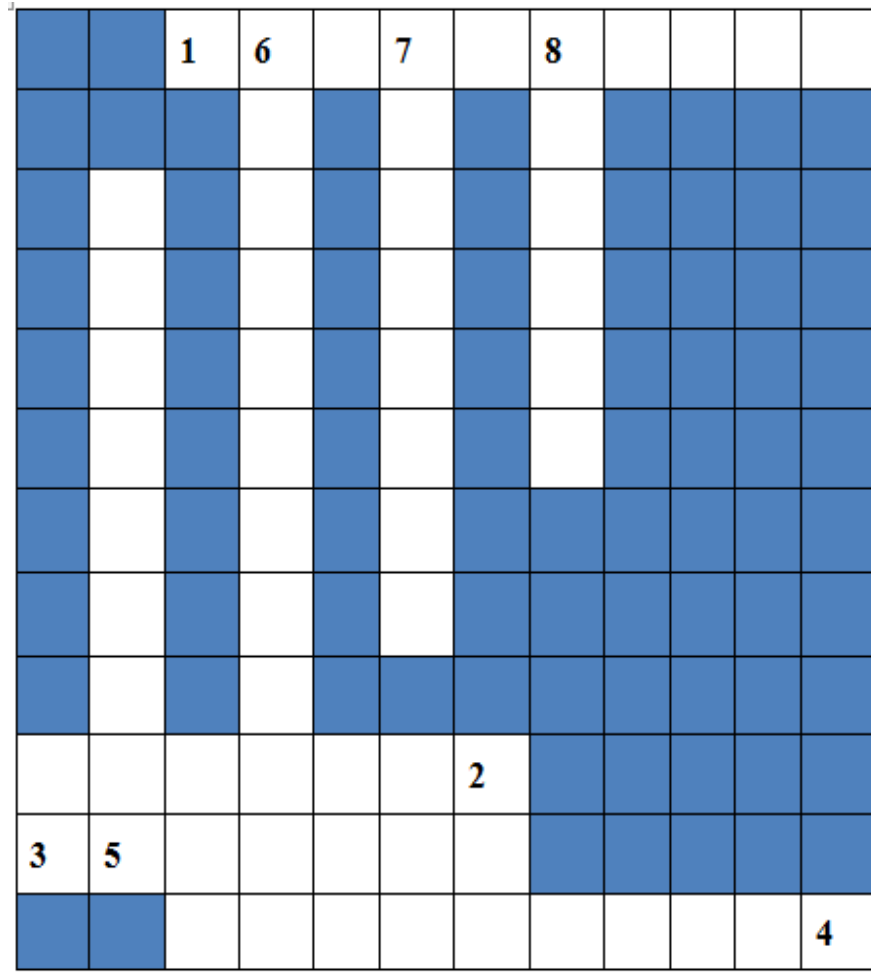

\section{Horizontal Questions}

1) It is a device which heats the feed water on its way to boiler by deriving heat from flue gases in thermal (or) steam power plant

2) The process of achieving uniform distribution in dielectric stress is called of cables.

3) ${ }_{92}^{235} \mathrm{U},{ }_{92}^{233} \mathrm{U},{ }_{94}^{239} \mathrm{PU} \longrightarrow$ materials

4) Mixing Indian rubber with mineral material such as sulphur, zinc oxide, red lead etc gives Indian Rubber which is an insulating material of underground cables.

\section{Vertical Questions}

5) If fission rate of chain reaction is to be control rods are moved out slightly.

6) Exhaust Steam is collected at of thermal (or) steam power plant.

7) Which gas is used in Gas-filled cables having pressure of $1400 \mathrm{kN} / \mathrm{m}^{2}$ ?

8) Jet type condenser is also known as condenser. type

\section{CONCLUSION}

Activity-Based Learning (ABL), made students learn various topics of PS-I in different ways also to know the importance of the course. These classroom activities motivate and create interest in learning power systems-I (PS-I) course.

\section{ACKNOWLEDGMENT}

I am thankful to II EEE 2017 batch Students, Our college principal, Vice-principal, HOD, EEE department faculty, entire college management, and Vishnu Educational Development Innovation Center (VEDIC), Hyderabad for valuable support. 


\section{REFERENCES}

[1] EDMODO tool for conducting quiz, student polls, assignments, course material sharing etc.

[2] Youtube animation videos of thermal/nuclear/gas power plants operation and working in 3-D view.

[3] Google/Wikipedia for information about various power systems - I (PS-I) topics.

[4] Google forms to collect student feedback about impact of Activity Based Learning (ABL) in learning Power Systems-I (PS-I).

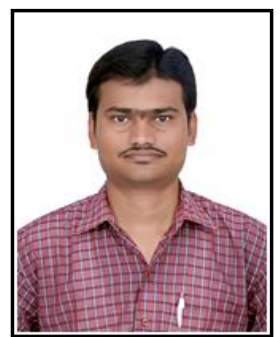

Author J.Venkatesh completed my Bachelor's Degree in Electrical and Electronics Engineering, PVP Siddhartha Institute of Technology (A), Vijayawada. I did my Master's degree in Power Systems \& Automation, SRKR Engineering College (A), Bhimavaram.

Since $9^{\text {th }}$ September 2014, I work as Assistant Professor in Electrical and Electronics Engineering (EEE), Shri Vishnu Engineering College for Women (Autonomous), Bhimavaram, West Godavari District, Andhra Pradesh. My area of interest is education research in engineering. Regarding the Electromagnetic Fields (EMF) course, I had received a certificate for "Outstanding Teaching Practices" as demonstrated at faculty colloquium held during the $13^{\text {th }}$ and $14^{\text {th }}$ December 2018 at Vishnu Educational Development Innovation Center (VEDIC), Aziz Nagar, Hyderabad. 